\title{
Los fantasmas mecánicos de la modernidad ${ }^{1}$
}

\section{Ghosts of modern mechanical}

\section{Lorena Antezana Barrios}

Instituto de la Comunicación e Imagen, Universidad de Chile

lorena.antezana@gmail.com

\section{Ricardo Ramírez Vallejos}

Instituto de la Comunicación e Imagen, Universidad de Chile ig.ramirezvallejos@gmail.com

\begin{abstract}
Resumen
La llegada de la fotografía a Chile, a pocos años de ser inventada, se convierte rápidamente en un elemento de distinción social. Desfilan en esas primeras imágenes los rostros de la elite y sus grandes obras y logros: ciudades, puentes, monumentos, además de instituciones que ordenan la vida cotidiana de los habitantes de ese territorio independiente: Iglesia, ejército y Estado. Postulamos en este trabajo que estas fotografías no son únicamente un registro histórico sino que son piezas clave que nos permiten "leer" las estrategias desplegadas por los grupos dominantes para construir un tipo de sociedad que fuese funcional a sus propósitos.
\end{abstract}

Palabras clave: Fotografía, imagen, Estado, ciudad, control social.

\begin{abstract}
When photography reached Chile a few years after its invention, it quickly became an element of social distinction. The first images are a series of portraits of the elite and their major projects - cities, bridges, monuments-as well as of the institutions that regulate daily life in this independent territory: church, army, and State. In this article, we suggest that these photographs are not solely historic documents, but rather they are keys that allow us to "read" the strategies used by dominant groups to build a society that would function on behalf of their interests.
\end{abstract}

1 Este artículo es parte de la Investigación "El ojo vigilante: lecturas visuales del poder", financiada por la Vicerrectoría de Investigación y Desarrollo de la Universidad de Chile. 
Keywords: Photography, image, state, city, social control.

\section{Introducción}

En 1843 la fotografía (aunque inicialmente se tratase de daguerrotipos) llega como novedad técnica a Chile de la mano de viajeros y aventureros, inicialmente extranjeros de origen inglés y francés (Rodríguez, 2001). Entre 1840 y 1860 estos fotógrafos se instalan en las principales ciudades ofreciendo sus servicios a una sociedad que comenzaba a perfilarse en una también naciente nación. La elite chilena aparece en estas imágenes junto a su principal creación inicial: la ciudad. Observando estos registros visuales históricos es que nos preguntamos: ¿cómo se presenta -para sí misma y para los demás- la oligarquía nacional? ¿Cuál es el valor político de las imágenes de "la" ciudad? ¿Cómo pueden estas fotografías brindar un sentido social y político común?

En ese sentido, nuestra perspectiva concibe a la fotografía, en tanto dispositivo tecnológico moderno, como operador de un régimen de visualidad que difunde un modelo de dominación a través de una puesta en escena que propone un ordenamiento social, un conjunto de valores acordes y que opera como un mecanismo de legitimación de la elite que detenta el poder dentro de una narrativa moderna en el contexto de la ciudad. De esta manera, las imágenes fotográficas tienen bastante más que aportar en cualquier revisión histórica, sobre todo cuando se tratan temáticas asociadas al poder, ya que este necesita de la producción simbólica para conservarse en el tiempo. Balandier indica que el poder no puede "mantenerse ni gracias a la dominación brutal ni basándose en la sola justificación racional. Para ello, no existe ni se conserva sino por la transposición, por la producción de imágenes, por la manipulación de símbolos y su ordenamiento de un cuadro ceremonial” (1994, p. 18).

Por tanto, lo que está en juego a través de las imágenes fotográficas es el fortalecimiento de un orden que dispone posiciones y condiciones particulares. La fotografía es una tecnología que, a través de una mirada no inocente, protege y legitima un sistema social marcado por el poder; contribuye, finalmente, a la creación de una realidad que: "es «formada» por una relación de poder mediante la cual el interés dominante se objetiva en orden” (Lechner, 2005, p. 190).Es aquí donde reside el nudo argumentativo de la presente ponencia. Lo que se busca es indagar en las relaciones jerarquizadas que marcaron la producción fotográfica chilena entre los años 1843 y 1930, dejando testimonio de la existencia de una mirada que contribuyó a la legitimación de la oligarquía como clase social llamada a regir el ordenamiento del estado nación chileno y de la ciudad como el espacio que permite "ubicarse" referencialmente, definir un conjunto de relaciones internas y externas y determinar 
los bordes, pues: "no vivimos en el interior de un vacío que cambia de color, vivimos en el interior de un conjunto de relaciones que determinan ubicaciones mutuamente irreductibles y en modo alguno superponibles" (Foucault, 1997, p. 2).

Ambas familias de fotografías responden a una determinada mirada en absoluto casual. La gran mayoría de los fotógrafos que se instalaron en Chile provenían del viejo mundo, lo que hizo que las poses y gestos de los modelos, así como los objetos y decorados que los acompañaban, siguieran esquemas determinados. En las fotografías de la elite analizadas se expresan tres valores centrales que construyeron la identidad de esta clase: tradición, tiempo libre y progreso. Lo mismo ocurrió con las fotografías de las ciudades en construcción donde se reflejan valores complementarios como urbanización, progreso y prestigio.

El presente artículo se basa en dos corpus de trabajo: el primero considera a las fotografías de ciudad, para lo cual se tomaron como referencia un total de 487 fotos del periodo comprendido entre 1840 y 1930. Las fotografías son parte de las colecciones patrimoniales disponibles en Chile en el Catálogo del Centro del Patrimonio Fotográfico CENFOTO, bajo las rúbricas de ciudad y urbano. El segundo corpus revisado corresponde a un universo de 4.645 fotografías de las colecciones disponibles en el Museo Histórico Nacional y en el Catálogo del Centro de Patrimonio Fotográfico -CENFOTO-. Se realizó un muestreo aleatorio de 10 fotografías por período de 10 años, logrando un corpus cualitativo de 70 fotografías que respondían a los siguientes criterios: (1) que hubiesen sido obtenidas en Chile entre 1843 y 1913 ; aunque no tuviesen fecha exacta determinada y (2) que apareciesen personas en ellas, pues se entiende que las construcciones de género surgen con la atribución de lugares diferenciados que se hace de los sujetos dependiendo de su formación biológica.

El método de análisis utilizado es fenomenológico, intentando realizar una lectura transversal, plural y abierta del corpus relacionándolo con perspectivas sociohistóricas y territoriales del periodo considerado. Por esta razón se hizo necesario volver al contexto etnográfico, pues los soportes visuales al permitirnos inteligibilizar los imaginarios simbólicos que hablan a través del texto nos reenvían a las categorías de pensamiento cultural de los sujetos sociales.

En este mismo sentido, la fotografía, como arte mecánica, sería: “la’ ficción de la modernidad, al ser el dispositivo tecnológico que permite romper las distancias e ingresar en una 'maquinaria panóptica” (Virilio, 1997, p. 4) que nos relaciona, pero también nos "controla". De esta manera, al mismo tiempo que la elite se muestra reafirmando su lugar en el país que se construye, también da a conocer, de una manera ejemplificadora, el "deber ser”, que regirá los cuerpos y espacio de esos otros no iguales con los que debe relacionarse en el territorio nacional. 


\section{La elite fotografiada}

En los primeros años de la fotografía en América del Sur, los fotógrafos eran los encargados de componer las imágenes a su voluntad, diciéndole a los retratados "dónde colocarse y qué actitud debían adoptar" (Burke 2005, p. 29). A través de poses sumamente preparadas, con escenarios construidos justamente para la obtención de imágenes y a partir de cierto tipo de tomas, encuadres y angulaciones; los fotógrafos construyeron, consciente o inconscientemente, una determinada visión de mundo que legitimó la posición de la oligarquía en el escenario nacional.

Es así como, sobre todo en una primera etapa, las fotografías se construyen en torno al respeto total hacia las tradiciones, consolidando el rol de la historia familiar como legitimador esencial y suficiente del poder de la clase a la que los sujetos fotografiados pertenecen. Mediante el retrato de estos cuerpos, en los que las costumbres, el peso de la tierra y los modos de vida heredados de la conquista española se mantienen como fuentes primarias de estatus y poder, el linaje y el respeto por el "buen nombre" se consolidan como elementos distintivos de una oligarquía tradicional. Se construye al mismo tiempo el relato de una familia -y mediante aquel, también el de una claseque está llamada, por destino, costumbre y acervo a posicionarse como aquella que debe marcar las directrices, el modelo en el que se desarrolle el país entero.

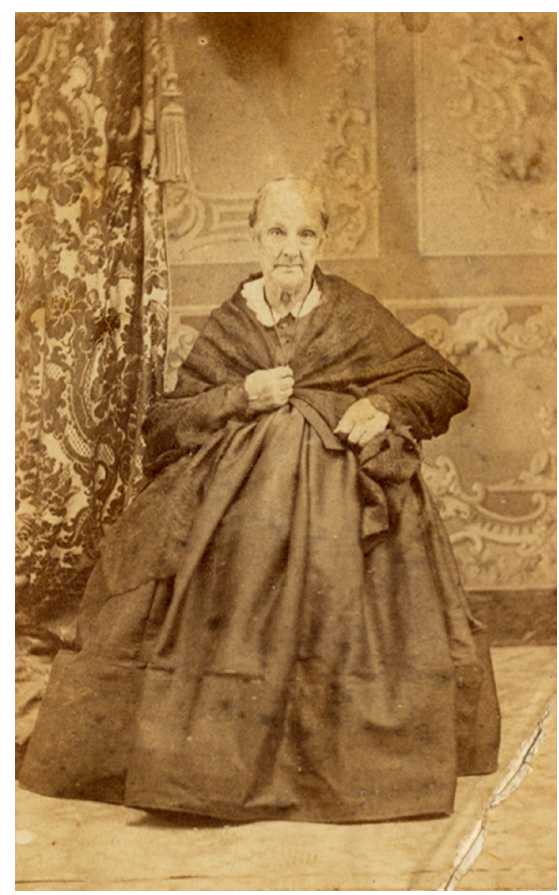

Imagen 1. Anónimo - 1867. CENFOTOUDP. 
La imágen 1 da cuenta de este acercamiento a la fotografía. La mujer que en ella se ve hace honor de una aristocracia tradicional. Mirada clara que interpela y cuerpo que parece frágil. Sin embargo, un detalle. La mano que con fuerza agarra la mantilla marca la determinación y la convicción de una generación que forjó su nombre en la sociedad chilena. Parece dirigirse a alguien -a su nieta según la dedicatoria ${ }^{2}$, pero de seguro a muchos más- y decirle cuál es la ruta que debe seguir. Marca un sentido que debe ser continuado luego de que ella muera. Esta anciana y su expresión es la personificación de una tradición ligada al control religioso -mantilla-, al ahorro y al orden.

Las imágenes muestran una actitud especial hacia la tradición, en tanto legitiman un sistema social que, para mantenerse, debe demostrar que está cimentado en valores anteriores. La mirada fotográfica pone en escena un ordenamiento basado en posiciones que trascienden la mera personificación, para transformarse en valores "propios" de la clase. Son, en definitiva, marcas valóricas compartidas, cuya ostentación se hace necesaria para la validación del orden. Mediante estas fotografías, el linaje de las familias se hace "vivo". En el ordenamiento de la sociedad chilena la imagen de un antepasado ilustre toma valor en tanto testimonio de la posición propia.

El poder de la elite nacional, sin embargo, no se construye solo sobre la exhibición del abolengo. Más bien, este se fundamenta en otros valores que son retratados en el cuadro fotográfico. Sobre todo cuando, ya avanzado el siglo XIX, el auge del comercio transforma a la posesión de dinero en "la clave del poder, la fuente del prestigio y la influencia personales" (Barros y Vergara, 1978, p. 75), dejando al "buen nombre” en una segunda posición.

La historia indica que la sociedad chilena de la segunda mitad del siglo XIX experimentaba profundos cambios. Se estaba asentando en el país una clase social que aglutinaba el poder económico (gracias a la concentración de los gravámenes ejercidos sobre la explotación salitrera) y el poder político (sobre todo después de la guerra civil de 1981, que significó el triunfo del movimiento parlamentarista).

En este contexto, las imágenes de la elite adquieren características particulares. La imagen de los hombres, si bien sufre diversas mutaciones a lo largo de la segunda mitad del siglo XIX, tiende a estar anclada en un factor determinante: la autoridad. Hay en la impronta masculina un sentido de dominación que se refleja en expresiones serias, renegando de la incorporación de objetos decorativos demasiado rimbombantes. Todo esto, sin embargo, con una salvedad: es a través de sus esposas e hijos que los hombres muestran sus riquezas. Mediante el lujo de sus familias y sus decorados, los hombres exhiben su propio lugar en el mundo.

2 En el reverso: "A mi nieta Lupercia, Carmen H. de V. Febrero 11 de 1867". Fuente: Catálogo CENFOTO-UDP. 


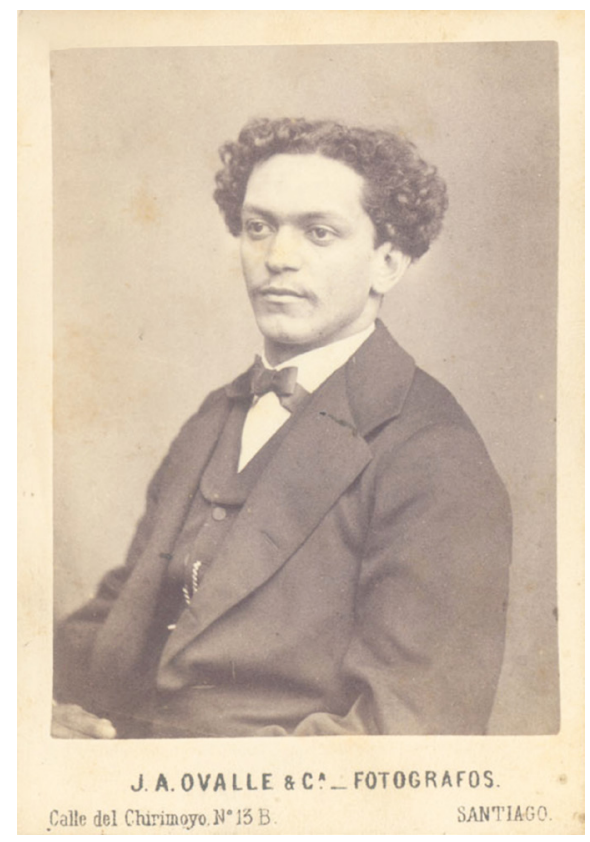

Imagen 2. L.A. Ovalle - 1867. CENFOTOUDP.

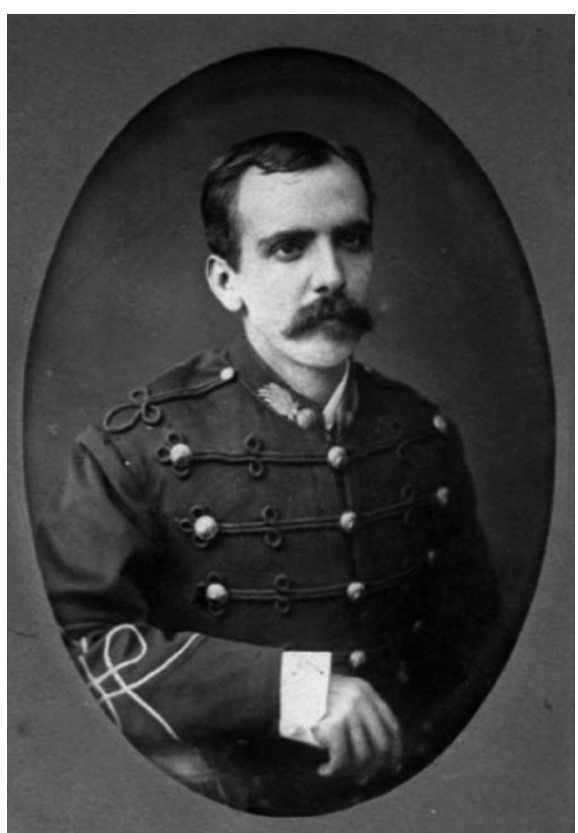

Imagen 3. Anónimo - 1879. Museo Histórico Nacional.

De cualquier forma, es en estos cuerpos fotografiados donde reside el control efectivo del país; ya sea a nivel económico y político (imagen 2) o militar (imagen 3), son estos hombres los llamados a manejar el destino del estado nación chileno. Cabe destacar en la imagen 3 un sentido distinto, propio del período histórico en la cual fue obtenida. La década del 70 trae consigo otro evento que modificará la representación masculina: la Guerra del Pacífico, conflicto armado que enfrentó a Chile, Perú y Bolivia entre 1879 y 1883.

Bajo una primera mirada, parecería que lo que se hace evidente aquí es cómo la fotografía se hace cargo de los roles asociados a lo femenino y lo masculino, haciéndolos vivos a través de la imagen. Ante los problemas políticos, económicos y sociales -públicos, finalmente-, el que se hace cargo, el que construye su imagen mostrándose sólido y capacitado para la resolución de los conflictos, es el hombre. Las mujeres, ostentosas y bellas, continúan con su vida de lujo, situándose en un espacio donde unicamente "son responsabilizadas del bienestar de sus propias familias" (Ortner y Whitehead, 1996, p. 140).

Sin embargo, la fotografía, cuya era "corresponde precisamente a la irrupción de lo privado en lo público” (Barthes, 1989, p. 169), trabaja en una dialéctica entre mantención y cambio; donde las mujeres adquieren la posibilidad de aparecer en imágenes que justamente establecen espacios de libertad. 
De cualquier forma, hombres y mujeres oligarcas comparten ciertos valores a la hora de aparecer en la imagen: la elegancia y la seguridad son distintivos que se leen a través de sus poses, expresiones, miradas y también objetos que conforman su puesta en escena: cortinajes, muebles, vestidos.

Por otro lado y como un sentido que se encuentra latente en todo el período estudiado, pero que sale a flote con firmeza después de la década de los 80 , cabe destacar la representación del poder como una mezcla de relajo calculado, libertad económica y expresión de una vida resuelta. Es la posesión del tiempo como un bien que no debe gastarse en labores productivas lo que conforma la imagen del poder de la clase acomodada. De esta manera, "la posibilidad de ocio y la obligación de trabajar definen quién es quién en la sociedad chilena del novecientos" (Barros y Vergara, 1978, pp. 50-51) y eso, finalmente, se expresa y se construye a través de las fotografías.

Con el cambio de siglo, la fotografía comienza a poner énfasis en la representación de grupos, marcando una diferencia notoria en lo que había sido el desarrollo de la técnica durante el siglo XIX. La construcción fotográfica comenzó a ser preferentemente pensada no solo con el fin de retratar a las personas en su calidad de sujetos, sino de formar una representación que incluyera una escena y objetos asociados. De esta forma, no es solo el individuo el que entra en la fotografía, sino todo su sistema de vida, sus costumbres y gustos.

En este contexto, la familia considerada "elemento crucial para el equilibrio social y la integración nacional" (Godoy, Hutchinson, Rosemblat y Zárate, 1995, p. 21), se transforma en el objeto fotográfico por excelencia. Es a través de este grupo de personas unidas por lazos de sangre y afecto que la clase acomodada chilena plantea un estilo, un deber ser que marca el camino hacia el futuro. Cabe destacar que las fotografías grupales comienzan a aumentar en el período inmediatamente anterior a la celebración del centenario de Chile. Es en estos años cruciales en los que se revisa lo hecho como nación, pero también se plantean los modos de seguir adelante. Con más pujanza se esboza un deber ser y una conciencia de superioridad moral mediante la cual “la oligarquía se legitima a sí misma” (Barros y Vergara, 1978, p. 81). 


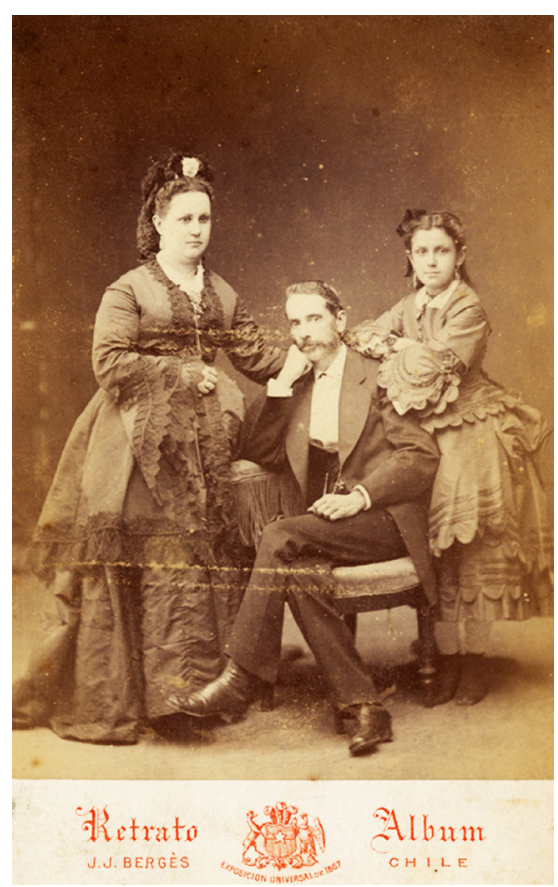

Imagen 4. J.J. Bergés - Sin fecha exacta, siglo XIX. CENFOTO-UDP.

La jerarquía que establece la imagen fotográfica no es solo la que se da dentro de las familias oligarcas. Esta no es más que el resultado de una anterior, más decisiva y determinante: la diferenciación que se instaura en torno a las clases sociales. Esta va más allá de la presencia casi absoluta de la oligarquía en la imagen -en desmedro de la clase popular que aparece en menor medida-. Aquíla posición diferenciada está dada por la forma en que la clase acomodada se presenta ante su contraparte. La imagen que estos proyectan se constituye en un dispositivo legitimador de su propio poder social.

"Lo que la fotografía no muestra es tan importante como lo que muestra" (Dubois, 1994, p. 160) y aquello que queda fuera de la representación visual es el grupo de chilenos cuyas características no deben ser asociadas al ethos nacional. Se trata de: "esa masa de chilenos no blancos, que no participaban de ninguna porción del poder nacional y que eran entendidos como vagabundos, delincuentes, borrachos, por el discurso hegemónico. Ellos eran los otros, el Otro radical, articulado con la clase hegemónica como lo absolutamente negativo" (Guzmán, 1996, p. 61).

Lo anterior se hace central pues, a través de las fotografías, lo que está en disputa es la construcción de la identidad de la nación. Proceso que se lleva a cabo "dentro del juego del poder y la exclusión” (Hall, 1996, p. 19), permitiendo que solo una porción de los habitantes del país conforme la impronta de este. En Chile, donde "la 
dominación hacia el novecientos permite que la oligarquía no solo controle el Estado, sino que sea el Estado mismo" (Barros y Vergara, 1978, p. 43), la imagen de la nación está dada por los ciudadanos educados. Los valores que ellos representan a través de la fotografía son los que merecen ocupar ese lugar, pues son los que deben ser seguidos.

\section{La tierra prometida: la ciudad}

La ciudad de Santiago, en 1843, necesitaba también dar cuenta de su modernización y requería por tanto de medios técnicos acordes con un lenguaje de lo instantáneo y exhibitivo, la fotografía permite "mostrar" el desarrollo de ese naciente país. El Estado Moderno reclama el control geográfico de un determinado territorio y construye su legitimidad a través de imágenes que han sido parte de su cuerpo político y le han dado su forma histórica. Organizar la mirada, definir las funciones y calcular el alcance de sus preceptos y leyes requiere una materialidad arquitectónica donde las cosas no se diluyan y se respeten las fronteras. La ciudad es el simulacro de la nación, ella exhibe la racionalidad desplegada sobre el conjunto anodino de historias, sujetos y épicas usados en las leyendas de la patria. En ese sentido, las fotografías analizadas nos remiten al territorio inicial de ese Chile naciente, nos indican -tanto por lo que muestran como por lo que esconden- lo importante, lo deseable y lo correcto.

El desafío es mayor entonces, puesto que la independencia trae consigo una serie de tareas que implican delimitar y trazar, en sentido literal y figurado, los límites y bordes del nuevo país. En sentido literal se dibujan las nuevas ciudades, lo que implica un reposicionamiento de los actores y una centralidad creciente del centro urbano por sobre el ámbito rural. En sentido figurado, se reordenan las relaciones en un marco distinto, el democrático.

Volviendo al origen, la población urbana en el Chile de 1813 era de aproximadamente el $10 \%$ de la población total del país mientras que en 1920 constituía el $42.8 \%$, uno de los porcentajes más altos de América Latina, debido en gran medida a: "la urbanización de una parte del peonaje itinerante [... Antes de 1840, los asentamientos habitacionales del 'bajo pueblo' eran extremadamente dispersos [... después de 1860 en cambio, las habitaciones del 'bajo pueblo' aparecían aglutinándose en torno y dentro de las grandes ciudades, configurando un fenómeno bastante visible” (Salazar, 2000, pp. 232-233).

Hacerse cargo de "ordenar" estas nuevas ciudades no era una tarea fácil, al tratarse, en el nuevo contexto democrático, de personas "libres". Por lo cual, delinear las ciudades de acuerdo a los estándares de los países modelo, o "desarrollados", implicaba domesticar a su población a través de distintos mecanismos. El ejercicio de la democracia y el establecimiento de ese orden requirió de una "pedagogía de la imagen, tan necesaria como lo fuera, en su momento, la de la lectura y la escritura, 
sobre la que se fundó la escuela republicana y con ella, la propia República" (Balandier, 1994, pp. 159-160).

Para emplear una imagen, podría decirse que "mientras la ciudad patricia estaba urbanísticamente dominada y moralmente regida por sus iglesias, conventos y capillas, el suburbio campesino lo estaba por sus quintas, cañadas y chinganas. Este contraste envolvía, obviamente, una oposición, que se hizo más aguda a medida que ambos, el suburbio campesino y el centro comercial patricio, se expandían, el uno sobre el otro" (Salazar, 2000, p. 123). En la fotografía de este periodo inicial lo que "aparece" es la ciudad patricia, el suburbio campesino no está en ella.

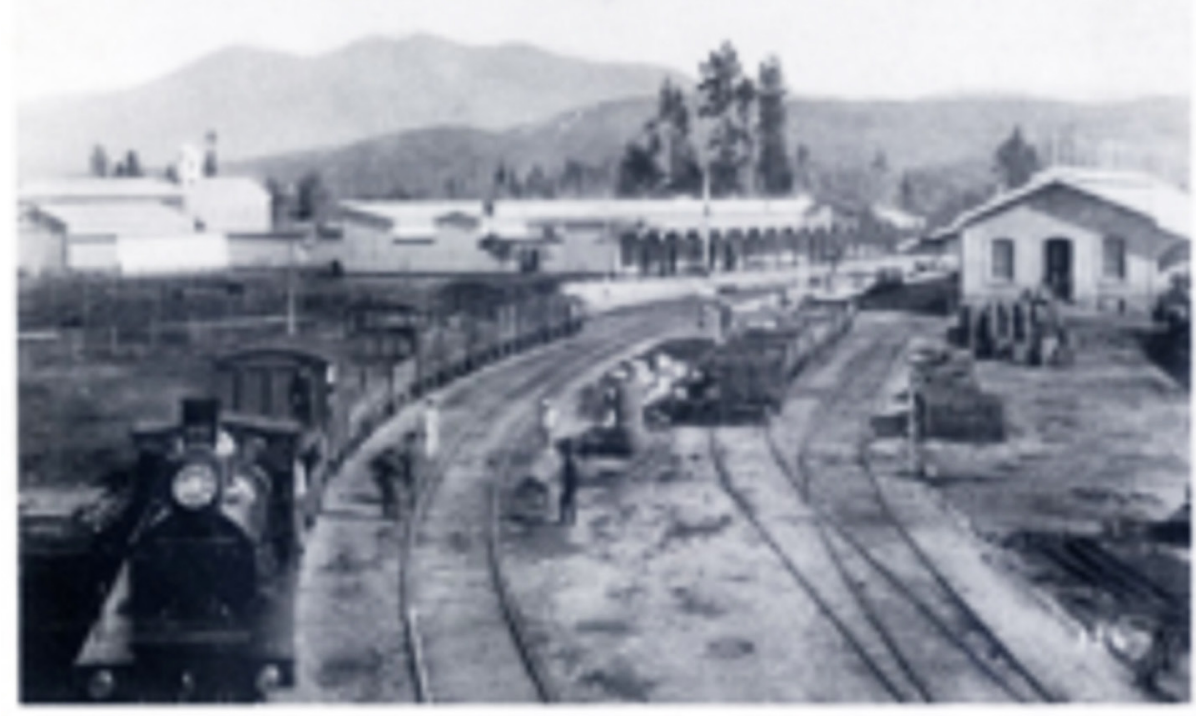

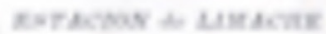

Imagen 5. Estación de Limache (1890 - 1900). CENFOTO-UDP.

La urbanización aparece reflejada en estaciones de ferrocarril, puentes, carreteras y muelles. También hay imágenes de riberas navegables que parecen controlar a la naturaleza en oposición a su irrupción en terremotos, maremotos e inundaciones, de los cuales también quedan registros. 


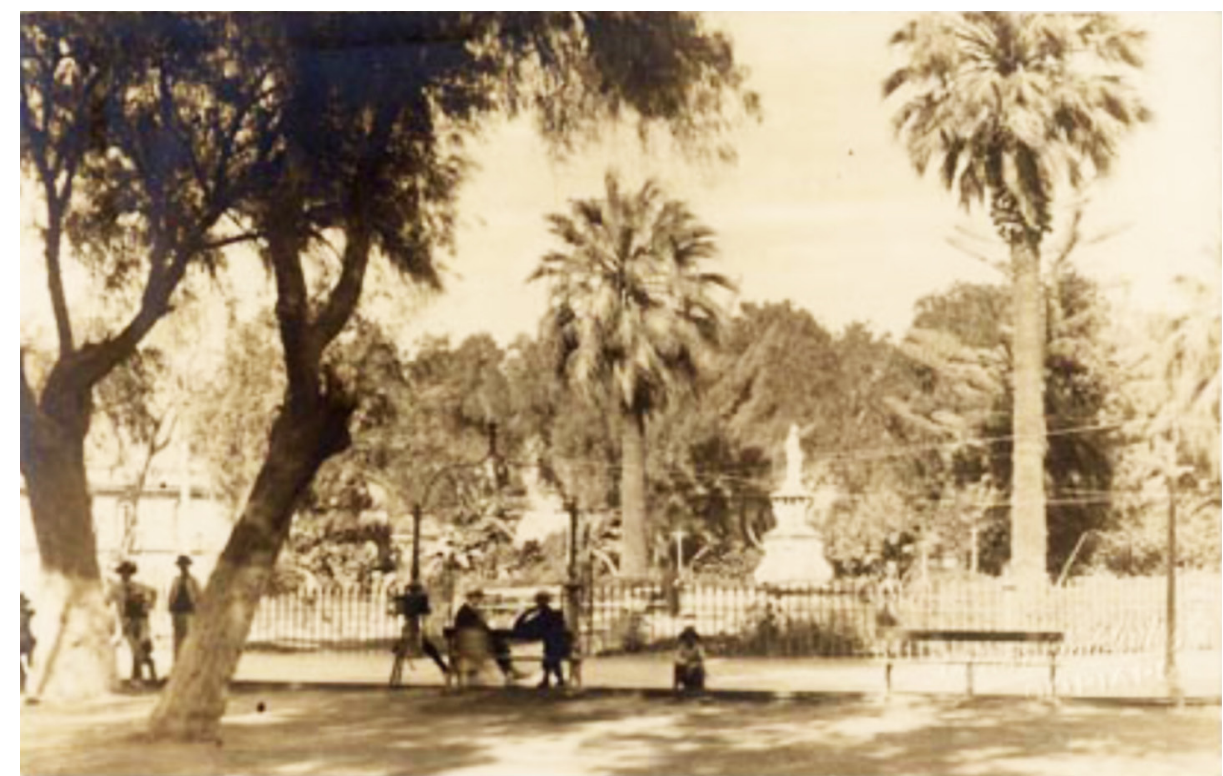

Imagen 6. Plaza de Armas de Copiapó. (s/fecha). CENFOTO-UDP.

De esta manera, el diseño de la ciudad fue regulando la vida cotidiana y segmentando espacialmente a sus pobladores. En este sentido, el que las villas fueran "pobladas" por los grandes terratenientes tuvo un significado específico puesto que su presencia "transformó las villas campesinas en una reproducción de los viejos pueblos de conquistadores: se situó la nobleza en los alrededores de la plaza, los mercaderes y artesanos en las calles intermedias y la gente pobre en los suburbios" (Salazar, 2000, p. 52; énfasis original).

El poder continúa en las manos de los mismos, de la elite criolla, pero esta se ubica en otro escenario, esta vez de la ciudad en la que "se erigen palacios, se exponen símbolos, se ejecutan rituales, se despliegan demostraciones públicas; como ocurría tanto en el pasado cercano como en el remoto" (Balandier, 1994, p. 116). 


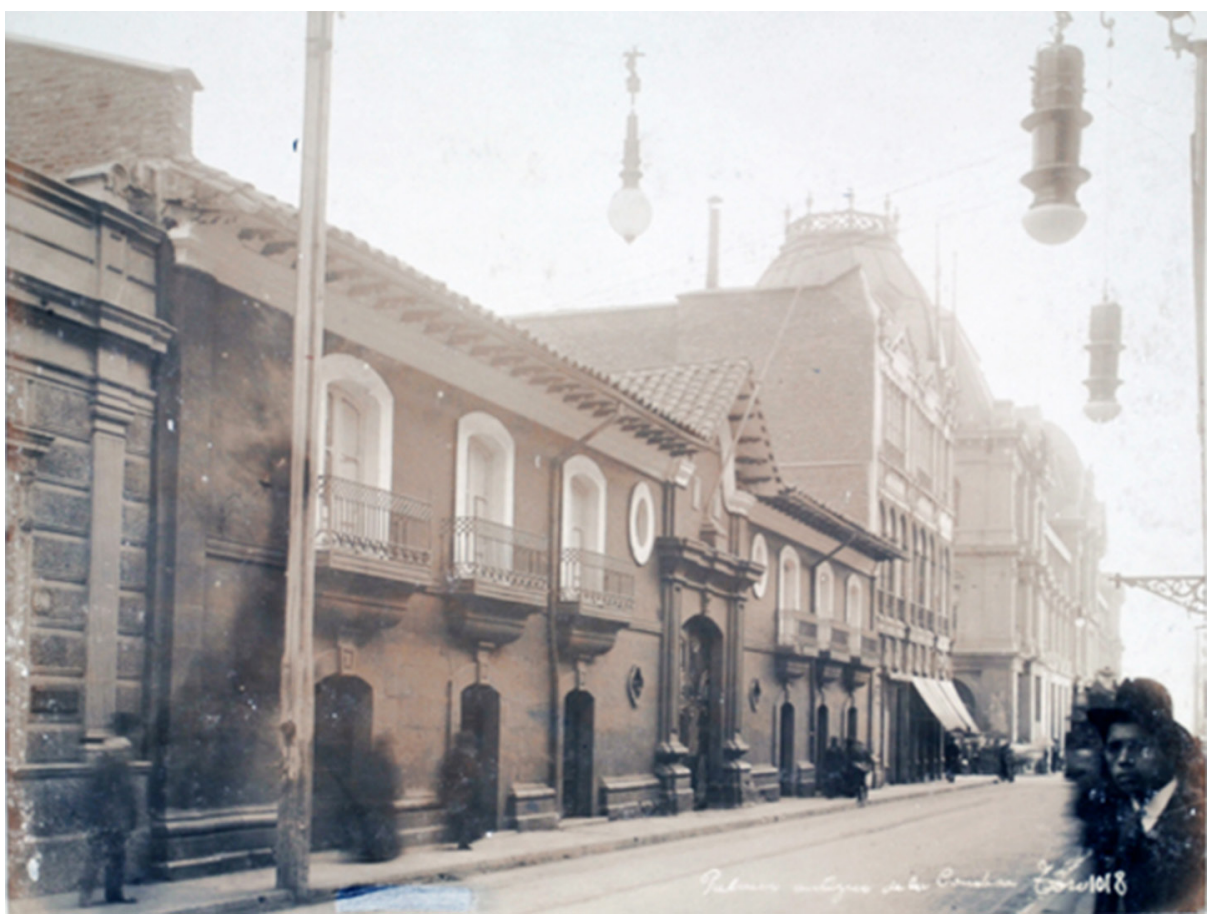

Imagen 7. Palacio Antiguo de la condesa Toro (s/fecha). CENFOTO-UDP.

A partir de 1870, se desarrolló una política de transacción, pues mientras por un lado las autoridades se esforzaban por implantar sobre los arrabales peonales el cuadrillado ajedrecístico-colonial de las calles y las fachadas de adobe y teja, por otro, los mercaderes pugnaban por mantener "la altísima concentración de miseria social por metro cuadrado de ciudad. La criatura que brotó de ese cruzamiento de escrúpulos urbanos e intereses mercantiles recibió un nombre especial: fueron los conventillos" (Salazar, 2000, p. 238). A partir de 1900 estos promovieron, "junto a otras realidades, la temible cuestión social que reventaría algunas décadas más tarde" (Salazar, 2000, p. 238; énfasis original).

Las imágenes de la ciudad en el Chile inicial dan cuenta de la ideología dominante (Sontag, 2006) al ofrecer una carta de navegación para el desarrollo de la sociedad a partir de una promesa - una utopía- que permite la construcción de un orden social donde se instala lo urbano por sobre lo rural, el centro por sobre la periferia; lo moderno por sobre lo tradicional.

\section{A modo de cierre}

¿Por qué, en una sociedad de "iguales" se acepta que unos pocos determinen la forma de vida de muchos otros? Esta pregunta nos remite a una discusión política, puesto 
que: "la política es el conflicto acerca del sentido del orden" (Lechner, 2005, p. 28) y en nuestro análisis, organizar la ciudad es también ordenar la vida cotidiana y al hacerlo, materializar la hegemonía de un grupo social que tendría la capacidad de "determinar el buen orden" (Lechner, 2005, p. 28).

La imagen fotográfica adquiere en la sociedad chilena - del siglo XIX- una función antropológica-jurídica; estético-social y económica-pedagógica al inventar la escena de un sujeto que exige ser presentado con sus propiedades simbólicas y materiales como la identidad nacional y la singularidad modernista.

El tipo de orden propuesto es "un orden en perpetua búsqueda y construcción, un objeto de deseo nunca plenamente alcanzado pero, por su mismo carácter de proceso inacabado, capaz de movilizar de manera constante las energías políticas y la subjetividad de los individuos en situaciones colectivas"(Lechner, 2005, pp. 9-10), es decir de una "promesa” de orden que, en el contexto histórico de una época de carencias y limitaciones aparece como un ideal de futuro compartido y deseado por tanto como una utopía que sería el lugar "sin espacio real. Son los espacios que entablan con el espacio real una relación general de analogía directa o inversa. Se trata de la misma sociedad en su perfección máxima o la negación de la sociedad, pero, de todas suertes, utopías con espacios que son fundamentales y esencialmente irreales" (Foucault, 1997, p. 3).

Las fotografías de la ciudad muestran, de manera evidente, todo aquello de lo cual la elite está orgullosa. Manifiestan e inmortalizan los procesos de independencia, a partir de la exhibición de los monumentos y la construcción de mitos heroicos; la organización de la sociedad a partir de una lógica nacionalista-democrática con la presentación de Instituciones modernas como las fachadas de Escuelas y Ministerios; y el progreso que se traduce visualmente como la domesticación de la naturaleza reflejada en puentes, industrias, muelles y riberas navegables.

En nuestro caso, la construcción de la ciudad a partir de la revisión de las imágenes fotográficas revisadas, parece el sentido de comunidad y de patria a través de distintos mecanismos de integración social como la religión, donde: "el cristianismo (la Iglesia Católica) es el intento más desarrollado de tal mediación entre la persona individual, la comunidad particular y el orden general” (Lechner, 2005, pp. 114-115) y la nueva doctrina militar donde: "el individuo existe en cuanto patriota" (Lechner, 2005, p. 117) aunque el patriotismo es una ficción, pero permite la mediación entre el individuo particular y el principio general del estado.

Las funciones políticas de las fotografías de este primer periodo son distintas de acuerdo a la clase social de los usuarios. En una primera etapa, 1840 - 1860, la elite "se muestra" frente a sus pares marcando el "deber ser" y "demuestra" su capacidad de ordenamiento con las fotos de sus "ciudades". Con la masificación de la fotografía, el "pueblo" accede a ella y, al hacerlo, también accede a una cierta estética que es fundamentalmente política, puesto que los fotógrafos ya habían impuesto ciertas 
normas acerca de lo fotografiable de acuerdo a los modelos que ellos mismos habían traído desde el extranjero, los cuales eran validados por la elite y asumidos como "realidad" por los restantes usuarios. De esta manera, la fotografía va expandiendo una cierta idea de ordenamiento social modelando cuerpos y también espacios.

\section{Referencias bibliográficas}

Balandier, G. (1994). El poder en escenas. De la representación del poder al poder de la representación. Buenos Aires: Paidós.

Barros, L. y Vergara, X. (1978). El modo de ser aristocrático. Santiago: Ediciones Aconcagua.

Barthes, R. (1989). La cámara lúcida. Barcelona: Paidós.

Burke, P. (2005). Visto y no visto: el uso de la imagen como documento histórico. Barcelona: Crítica.

Dubois, P. (1994). El acto fotográfico: representación a recepción. Barcelona: Paidós. Foucault, M. (1997). “Des espaces autres”. Conferencia pronunciada en el Centre d'Études architecturales el 14 de marzo de 1967 y publicada en Architecture, Mouvement, Continuité, n 5, octubre 1984, págs. 46-49. Traducción al español por Luis Gayo Pérez Bueno, publicada en revista Astrágalo, n 7, septiembre de 1997.

Godoy, L., Hutchison, E., Rosemblatt, K. y Zárate, M. (Eds.). (1995). Disciplina y desacato: construcción de identidad en Chile, siglos XIX y XX. Santiago: SURCEDEM.

Guzmán, J. (1996). Ejes de lo femenino/masculino y de lo blanco/no blanco. En Acuña, M. y Montecinos, S. (Eds.), Diálogos sobre el género masculino en Chile (pp. 49-61). Santiago: Ediciones de la Universidad de Chile.

Hall, S. (1996). ¿Quién necesita identidad?. En Hall, S. y du Gay, P. (Eds.), Cuestiones de identidad cultural (pp. 13-39). Buenos Aires: Amorrortu.

Lechner, N. (2005). Obras Escogidas. Santiago: LOM.

Ortner, S. y Whitehead, H. (1996). Indagaciones acerca de los significados sexuales. En Lamas, M. (Ed.), El género: construcción cultural de la diferencia sexual (pp. 127-179). Ciudad de México: PUEG.

Rodríguez, H. (2001). Fotógrafos en Chile durante el siglo XIX. Santiago: Centro Nacional del Patrimonio Fotográfico.

Salazar, G. (2000). Labradores, peones y proletarios. Santiago: LOM.

Sontag, S. (2006). Sobre la fotografía. Ciudad de México: Alfaguara.

Virilio, P. (1997). Fin de l'histoire, ou fin de la géographie? Un monde surexposé. En Le Monde Diplomatique, agosto. 